\title{
Effect of Indoor Concentrate Feeding vs. Outdoor Grazing on the Expression of Genes Involved in Muscle Growth and Nutrient Content in Japanese Black Steer Muscle
}

\author{
Masahiro Shibata*, Kazunori Matsumoto, Yasuko Hikino, Naoyuki Yamamoto \\ Livestock Production and Wildlife Management Research Division, NARO Western Region Agricultural Research \\ Center, Shimane, Japan \\ Email: shibatam@affrc.go.jp
}

Received 30 July 2014; revised 15 September 2014; accepted 30 September 2014

Copyright (C) 2014 by authors and Scientific Research Publishing Inc.

This work is licensed under the Creative Commons Attribution International License (CC BY). http://creativecommons.org/licenses/by/4.0/

(c) (7) Open Access

\section{Abstract}

The objective of the present study was to investigate the effect of outdoor grazing on the expression of genes involved in muscle growth and the nutrient contents of skeletal muscle in steers. Ten Japanese Black steers were divided into two groups: grazing (GR) and concentrate (CT) groups. Crude protein, extractable lipid, moisture, fatty acid, cooking loss and Warner Bratzler shear force in muscle tissue were analyzed. The gene expression of myosin heavy chain (MyHC) isoform ( $2 \mathrm{a}$, $2 \mathrm{x}$ and slow), myostatin, follistatin, peroxisome proliferator-activated receptor $\gamma 2$ (PPAR $\gamma 2$ ), CCAAT/enhancer binding protein $\alpha$ (C/EBP $\alpha$ ), heat shock protein (HSP) 27 and HSP40 in skeletal muscles was evaluated at the end of fattening. Decreases in MyHC-2a and MyHC-2x (fast-twitch fiber type) expression in the longissimus lumborum (LL) muscle were detected in the GR group compared with the CT group; in contrast, an increase in MyHC-slow (slow-twitch fiber type) expression was shown in the GR group. These results suggest that grazing initiated muscle fiber type conversion to slow-twitch from fast-twitch. A decrease in extractable lipid content was observed in the GR group in the LL and semitendinosus (ST) muscles. Crude protein content in the LL muscle in the GR group was higher than in the CT group. MyHC expression in LL muscle in the GR group was greater than in the CT group. A decrease in myostatin and PPAR $\gamma 2$ gene expression was detected in the GR group compared with the CT group in both muscles. Expression of C/EBP $\alpha$ in LL muscle in the GR group was lower than in the CT group. These results suggest that grazing steers at the end of fattening may lead to an increase in protein content and a decrease in fat accumulation in LL and/or ST muscles by regulation of myostatin, MyHC, PPAR $\gamma 2$ and C/EBP $\alpha$ gene expression.

*Corresponding author.

How to cite this paper: Shibata, M., Matsumoto, K., Hikino, Y. and Yamamoto, N. (2014) Effect of Indoor Concentrate Feeding vs. Outdoor Grazing on the Expression of Genes Involved in Muscle Growth and Nutrient Content in Japanese Black Steer Muscle. Open Journal of Animal Sciences, 4, 297-304. http://dx.doi.org/10.4236/ojas.2014.45038 


\section{Keywords}

\section{Grazing, Gene Expression, Japanese Black Steer, Muscle Growth, Nutrient Content}

\section{Introduction}

Beef cattle in Japan are reared indoors on a concentrate-based diet throughout the fattening period. Our previous study revealed that feeding a large amount of grass hay to steers indoors induced an increase in protein content and a decrease in fat accumulation in muscle by regulating myostatin, myosin heavy chain (MyHC) and CCAAT/ enhancer binding protein $\alpha(\mathrm{C} / \mathrm{EBP} \alpha)$ gene expression [1]. Myostatin has been shown to be a negative regulator of skeletal muscle growth, and its function is engaged in both hypertrophy and hyperplasia of skeletal muscle [2]. The MyHC protein is the major component of the thick filament in skeletal muscle, and is the most abundant myofibril protein. C/EBP $\alpha$ and peroxisome proliferator-activated receptor $\gamma(\operatorname{PPAR} \gamma)$ have been shown to play an important role in activating adipogenesis [3] [4] and these two genes are expressed in the late stage of adipocyte differentiation [5]. Follistatin has been shown to bind to myostatin and inhibit its activity, and its overexpression in transgenic mice has been shown to increase skeletal muscle growth [6]. Bernard et al. [7] reported that expression of heat shock protein (HSP) 40 in muscle is associated with beef tenderness. Another study reported that the drip loss, crude fat content and monounsaturated fatty acid concentrations in muscle of pasturefed Japanese Shorthorn steers were lower than those of concentrate-fed steers, and pasture finishing increased the $\alpha$-tocopherol and $\beta$-carotene contents in muscle [8]. The protein content in muscle was lower in grass-fed cattle than in cattle fed a combination of grass and concentrate [9]. Schroeder et al. [10] reported that the crude fat content in muscle was lower in forage-fed steers compared with in concentrate-fed steers.

Although the muscle nutrient content in roughage-fed steers has been described in several reports, there are no reports on the relationship of gene expression and nutrient content under grazing conditions. The objective of this study was to investigate the relationship of changes in gene expression involved in muscle growth and nutrient content in skeletal muscle between outdoor grazed and indoor concentrate-fed steers.

\section{Methodology}

\subsection{Animal Management}

Management of steers and all procedures were performed according to the Animal Experimental Guidelines of the NARO Western Region Agricultural Research Center (NARO/WARC), Japan. Ten 10-month-old Japanese Black steers (254 $\pm 8.0 \mathrm{~kg}$ ), which had been bred at NARO/WARC, were used in this study. Steers were randomly divided into two groups: the grazing (GR) group and concentrate (CT) group. They were first housed individually in a stall barn and fed concentrate (flaked corn, flaked barley, wheat bran, and soybean meal; 73\% total digestible nutrients [TDN] and $11 \%$ crude protein [CP]) ad libitum, and Italian ryegrass hay (59\% TDN and $7.2 \% \mathrm{CP}$ ) at $1.5 \mathrm{~kg} /$ day until 21 months of age. After this control period, the four steers of the GR group $(533 \pm 24.3 \mathrm{~kg}$ ) were placed on an outdoor pasture; in contrast, the remaining six steers of the CT group (562 \pm $29.0 \mathrm{~kg}$ ) continued to be fed the concentrate and grass hay diet in the stall barn. The steers were slaughtered at 27 months of age at the NARO/WARC abattoir, and skeletal muscle tissues from the longissimus lumborum (LL) and semitendinosus (ST) muscles were obtained for analysis of the gene expression and meat characteristics. A portion of these samples was rapidly frozen in liquid nitrogen and stored at $-80^{\circ} \mathrm{C}$ until RNA extraction.

\subsection{Meat Characteristics}

Collected muscles were processed into 2.5-cm (thickness) steaks, vacuum-packed, stored in a refrigerator at $2^{\circ} \mathrm{C}$ for 15 days after slaughter, and frozen at $-80^{\circ} \mathrm{C}$ until analysis. Steaks were thawed for $24 \mathrm{~h}$ at $2^{\circ} \mathrm{C}$ and then carefully mopped dry using paper tissue. The samples were broiled on electric grills to an internal temperature of $70^{\circ} \mathrm{C}$; they were then wrapped in plastic to prevent desiccation and stored at $2^{\circ} \mathrm{C}$ for approximately $12 \mathrm{~h}$. Cooking loss was calculated from the weight difference between before and after cooking [11]. Six cores (1.3 $\mathrm{cm}$ in diameter) were removed from each steak parallel to the longitudinal orientation of the muscle fibers. All cores were sheared using a Warner-Bratzler shear force (WBSF) machine, and the peak shear force was recorded 
[11]. A portion of muscle tissue except subcutaneous fat and intermuscular fat was minced to determine the crude protein content, extractable lipid content and moisture content. Crude protein was calculated by quantitative analysis of nitrogen using the Kjeldahl method with copper sulfate and potassium sulfate as catalysts [12]. Lipid was extracted with diethyl ether for $16 \mathrm{~h}$ using a Soxhlet extractor [12]. To analyze the fatty acid composition in the muscle tissue, the extracted lipid was converted to fatty acid methyl esters by boron trifluoride methanol complex methanol solution and analyzed using gas chromatography [13].

\subsection{RNA Isolation and Quantitative Real-Time PCR}

Total RNA was extracted from muscle tissues using TRIZOL reagent (Invitrogen, Carlsbad, CA, USA) according to the manufacturer's protocol. The RNA quality was assessed using a Multiskan GO UV/Vis spectrophotometer (Thermo Fisher Scientific, Waltham, MA, USA). The first-strand complementary DNA (cDNA) was synthesized from $3 \mu \mathrm{g}$ of total RNA using SuperScript II RNase $\mathrm{H}^{-}$reverse transcriptase (Invitrogen) with oligo (dT) primer (Amersham Pharmacia Biotech, Piscataway, NJ, USA). After reverse transcription, gene expression of MyHC, MyHC isoforms (-2x, -2a, and -slow), myostatin, follistatin,PPAR $\gamma 2$, C/EBP $\alpha$, HSP 27 and HSP 40 were determined by real-time PCR using an ABI 7500 detection system (Applied Biosystems, Foster City, CA, USA). Real-time PCR analyses were carried out at least in duplicate for each sample. The expression of the MyHC gene was represented as the sum of MyHC-2x, -2a, and -slow gene expression. The first-strand cDNA was diluted with deionized water and amplified using SYBR Green PCR Master Mix or TaqMan Universal PCR Master Mix (Applied Biosystems) with the gene-specific TaqMan probe and primers (Table 1). The real-time PCR reaction was carried out initially for $2 \mathrm{~min}$ at $50^{\circ} \mathrm{C}$, then for $10 \mathrm{~min}$ at $95^{\circ} \mathrm{C}$, then 50 cycles of $15 \mathrm{~s}$ at $95^{\circ} \mathrm{C}$ and $1 \mathrm{~min}$ at $60^{\circ} \mathrm{C}$. The housekeeping gene glyceraldehyde-3-phosphate dehydrogenase (GAPDH) was used as a normalization control. The TaqMan probe and primers were designed using Primer Express (Applied Biosystems).

\subsection{Statistical Analysis}

Gene expression data were represented as means. The relationships between the relative mRNA levels of the target genes or nutrient content and treatment groups were analyzed using one-way ANOVA and a post-hoc Fisher test. A $p$ value of $<0.05$ was considered statistically significant.

\section{Results and Discussion}

Table 2 shows the nutrient contents in the LL and ST muscles of the GR and CT groups in steers. A previous study reported that no change in protein content was found in the longissimus muscle between combination feeding of concentrate and a large amount of roughage vs. concentrate feeding alone in steers [10] [14]. Fur-

Table 1. Sequences of real-time PCR primers used in this study ${ }^{1}$.

\begin{tabular}{|c|c|c|c|c|}
\hline Gene $^{2}$ & $\begin{array}{c}\text { GenBank } \\
\text { Accession No. }\end{array}$ & $\begin{array}{c}\text { Forward primer } \\
\text { (5' to 3') }\end{array}$ & $\begin{array}{l}\text { Reverse primer } \\
\text { (5' to 3') }\end{array}$ & $\begin{array}{l}\text { Product } \\
\text { size, bp }\end{array}$ \\
\hline MyHC-2a & AB059398 & GGTAACAAGGACCTCTGAGTTC & ATGGCCATGTCCTCGATCTTG & 308 \\
\hline MyHC-2x & АВ059399 & GTCTTTGATTGGGCTGCCATC & ATGGCCATGTCCTCGATCTTG & 313 \\
\hline MyHC-slow & AB059400 & TGTGCCTGATGACAAAGAGGAG & ATGGCCATGTCCTCGATCTTG & 162 \\
\hline Myostatin & АB076403 & GGCCATGATCTTGCTGTAACCT & GCATCGAGATTCTGTGGAGTG & 144 \\
\hline Follistatin & NM175801 & ACCTACCGCAACGAATGTGC & CTGTTCAGAGGAGGTGGGCTC & 201 \\
\hline $\operatorname{PPAR} \gamma 2$ & Y12420 & TGGGAGTCGTGGCAAATCC & CCAAAACGGCATCTCTGTGTC & 151 \\
\hline $\mathrm{C} / \mathrm{EBP} \alpha$ & NM176784 & AGCGCCGCTTTCGGCTTTC & GCTGATGTCGATGGACGTCT & 114 \\
\hline HSP 27 & NM1025569 & TCCCTGGACGTCAACCACTT & GGTGACGGGAATGGTGATCT & 261 \\
\hline HSP 40 & NM1015637 & CGTTGTCCATCAACTTACAG & CACCTCGGCCTTCACATTTG & 107 \\
\hline GAPDH & U85042 & TGACСССТTCATTGACСТTСA & ACCCCAGTGGACTCCACTACAT & 201 \\
\hline
\end{tabular}

${ }^{1}$ All sequence data were from bovine sequence. ${ }^{2} \mathrm{MyHC}$, myosin heavy chain; PPAR $\gamma 2$, peroxisome proliferator-activated receptor $\gamma 2$; C/EBP $\alpha$, CCAAT/enhancer binding protein $\alpha$; HSP 27, heat shock protein 27 kDa; HSP 40, heat shock protein 40 kDa; GAPDH, glyceraldehyde-3-phosphate dehydrogenase. 
Table 2. Nutrient contents, cooking loss and Warner-Bratzler shear force (WBSF) in the M. longissimus lumborum (LL) and M. semitendinosus (ST) muscles of the GR and CT groups in Japanese Black steers.

\begin{tabular}{|c|c|c|c|c|}
\hline & \multicolumn{2}{|c|}{ LL } & \multicolumn{2}{|c|}{ ST } \\
\hline & GR & CT & GR & CT \\
\hline Crude protein, \% & $19.7 \pm 0.38^{*}$ & $17.0 \pm 0.57$ & $19.9 \pm 0.31$ & $19.7 \pm 0.25$ \\
\hline Extractable lipid, \% & $11.3 \pm 1.46^{*}$ & $24.0 \pm 2.12$ & $4.4 \pm 0.34^{*}$ & $9.5 \pm 0.88$ \\
\hline Moisture, \% & $67.9 \pm 1.08^{*}$ & $57.8 \pm 1.56$ & $74.2 \pm 0.33^{*}$ & $69.3 \pm 0.69$ \\
\hline \multicolumn{5}{|l|}{ Fatty acid composition } \\
\hline SFA, $\%$ & $41.3 \pm 1.56$ & $42.6 \pm 0.99$ & $45.2 \pm 1.27$ & $45.2 \pm 0.97$ \\
\hline MUFA, \% & $52.7 \pm 1.13$ & $52.4 \pm 1.38$ & $47.7 \pm 0.79$ & $48.9 \pm 1.01$ \\
\hline PUFA, \% & $3.1 \pm 0.33$ & $2.3 \pm 0.26$ & $4.4 \pm 0.40^{*}$ & $3.3 \pm 0.11$ \\
\hline Cooking loss, $\%$ & - & - & $41.8 \pm 1.01$ & $37.6 \pm 1.86$ \\
\hline WBSF, kg & - & - & $3.2 \pm 0.07$ & $2.6 \pm 0.26$ \\
\hline
\end{tabular}

GR: grazing group, CT: concentrate group. Values are expressed as means \pm SEM. ${ }^{*} p<0.05$. SFA: saturated fatty acid (sum of C14:0, C15:0, C16:0, C17:0, and C18:0), MUFA: monounsaturated fatty acid (sum of C14:1, C16:1, C17:1, C18:1, and C20:1), PUFA: polyunsaturated fatty acid (sum of C18:2, C18:3, C20:3, C20:4, and C22:5).

thermore, Srinivasan et al. [9] observed that the protein content in muscle was lower in grass-fed cattle than in cattle fed a combination of grass and concentrate. On the other hand, crude protein content in the ST muscle was greater in the grass hay-fed than in the concentrate-fed steers [15]. In agreement with previously published reports, we found crude protein in the LL muscle of the GR group was significantly greater than that of the CT group, even though there was no significant difference in protein content in the ST muscle between the two groups (Table 2). This corresponded to the gene expression in steer muscles. Myostatin has been shown to play a negative regulatory role in skeletal muscle growth, and its function is involved in both hypertrophy and hyper plasia of skeletal muscle [2]. Expression of the myostatin gene in the LL and ST muscles of the GR group was significantly lower than that of the CT group (Table 3). Furthermore, although there was no change in MyHCgene expression in the ST muscle between the two groups, its expression in the LL muscle of the GR group was significantly greater than that of the CT group (Table 3). A previous study revealed that the protein content in skeletal muscle is affected by the regulation of myostatin and MyHC gene expression when steers are fed a large amount of grass hay indoors [1]. Although there is competitive action between myostatin and follistatin, there was no significant difference in follistatin gene expression in both muscles between two groups (Table 3). The present study suggests that grazing at the end of fattening may increase the protein content in the skeletal muscle by the expression of myostatin and MyHC genes.

A change in the distribution ratio of the three MyHC isoforms was identified in the LL muscle between the two groups (Figure 1). The expression ratio of the MyHC-2a and -2x (fast-twitch) genes in the LL muscle was significantly lower in the GR group than in the CT group. In contrast, the expression ratio of the MyHC-slow (slow-twitch) gene in the LL muscle of the GR group was significantly greater than that of the CT group. No change in the distribution ratio of MyHC isoforms was identified in the ST muscle. A previous study reported that muscle fiber type was converted to slow-twitch from fast-twitch with changes in the expression of glycolytic enzymes when cattle were grazed in the latter fattening period [16]. In terms of the expression of MyHC isoforms when steers were grazed at the end of fattening, the present study agreed with previous reports. Moreover, a previous report indicated that whole body exercise training caused a fast-twitch to slow-twitch shift in the MyHC isoform in rat hindlimb muscles [17]. The present results suggested that muscle fiber type conversion to slow-twitch from fast-twitch occurred in grazed steer muscle by simply grazing and/or exercise stimulus by grazing.

Extractable lipid in the LL and ST muscles of the CT group was significantly higher than that of the GR group (Table 2). The crude fat content in muscle of concentrate-fed Japanese Shorthorn steers was greater than that of pasture-fed steers [8]. Schroeder et al. [10] also reported that the crude fat content in muscle was higher in concentrate-fed steers compared with forage-fed steers. Furthermore, our previous study indicated that extractable lipids in LL and ST muscles were higher in the concentrate-fed steers than in the hay-fed steers [15]. 


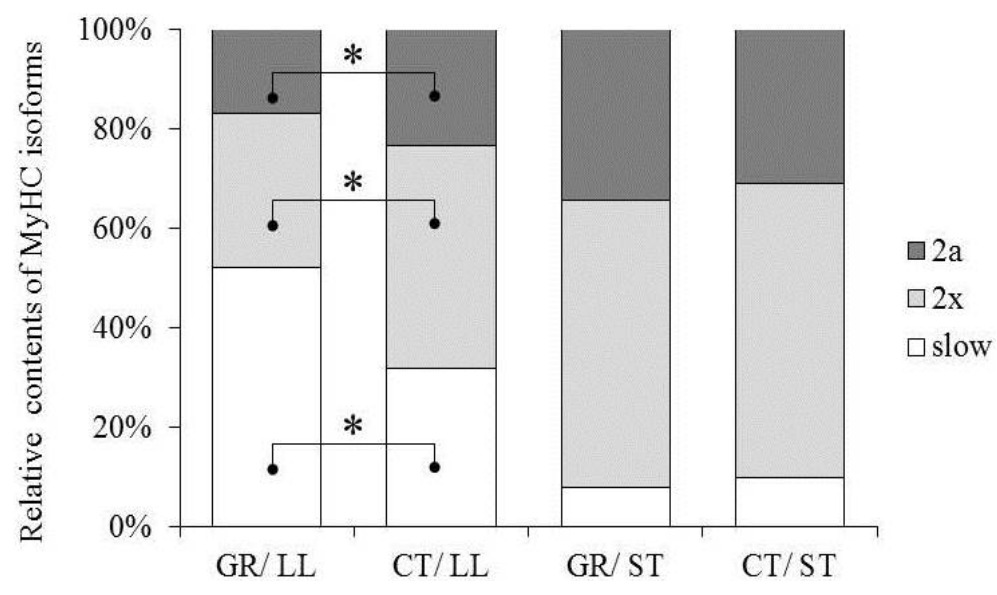

Figure 1. mRNA composition of myosin heavy chain (MyHC) isoforms (-2a, $-2 \mathrm{x},-$ slow) in the longissimus lumborum (LL) and semitendinosus (ST) muscles of Japanese Black steers. The composition of MyHC isoforms is indicated as the ratio of each isoform to the total MyHC isoforms. An asterisk indicates that the means differ significantly between the GR group and CT group steer of the same isoform $(p<0.05)$. GR: grazing group, CT: concentrate group.

Table 3. Genes expression in the M. longissimus lumborum (LL) and M. semitendinosus (ST) muscles of the GR and CT groups in Japanese Black steers.

\begin{tabular}{ccccc}
\hline & \multicolumn{2}{c}{ LL } & \multicolumn{2}{c}{ ST } \\
\cline { 2 - 5 } & GR & CT & GR & CT \\
\hline Myostatin & $0.20 \pm 0.03^{*}$ & $0.33 \pm 0.04$ & $0.30 \pm 0.05^{*}$ & $0.50 \pm 0.05$ \\
Myosin heavy chain & $15.83 \pm 3.46^{*}$ & $8.22 \pm 0.41$ & $8.97 \pm 3.68$ & $6.80 \pm 0.89$ \\
Follistatin & $19.40 \pm 2.63$ & $15.69 \pm 2.29$ & $10.18 \pm 3.22$ & $12.67 \pm 1.08$ \\
& & & & \\
PPAR $\gamma 2$ & $0.64 \pm 0.06^{*}$ & $2.23 \pm 0.41$ & $1.85 \pm 0.31$ \\
C/EBP $\alpha$ & $1.08 \pm 0.27^{*}$ & $1.96 \pm 0.25$ & & $2.85 \pm 0.42$ \\
HSP 27 & & & & \\
HSP 40 & $0.63 \pm 0.17^{*}$ & $1.06 \pm 0.09$ & $0.16 \pm 0.03$ & $0.56 \pm 0.15$ \\
\hline
\end{tabular}

GR: grazing group; CT: concentrate group. Values are expressed as means \pm SEM and as relative gene mRNA abundance. These genes expression are normalized by the housekeeping gene glycelaldehyde-3-phosphate dehydrogenase. ${ }^{*} p<0.05$. PPAR 2 : peroxisome proliferator-activated receptor $\gamma 2$; $\mathrm{C} / \mathrm{EBP} \alpha$ : CCAAT/enhancer binding protein $\alpha$; HSP 27: heat shock protein $27 \mathrm{kDa}$; HSP 40: heat shock protein $40 \mathrm{kDa}$.

Our present results coincided with our previously published study. C/EBP $\alpha$ and $\operatorname{PPAR} \gamma$ have been shown to play an important role in activating adipogenesis [3] [4]. Yamada et al. [18] revealed that fat accumulation in skeletal muscle at the end of the fattening period was affected by the increase in the expression of C/EBP $\alpha$ during indoor feeding of large amounts of concentrate to steers. Expression of the C/EBP $\alpha$ gene in the LL muscle of the GR group was significantly lower than that of the CT group (Table 3). The PPAR $\gamma 2$ gene expression was also significantly lower in the LL and ST muscles of the GR group compared with those of the CT group (Table 3). Expression of PPAR $\gamma 2$ gene in the LL and ST muscles at the end of fattening tended to be lower in the grass hay-fed steers than in the concentrate-fed steers [1]. Previous studies with myostatin-deficient mice observed a decrease in body fat accumulation resulting from a reduction of adipogenesis; accordingly, leptin secretion was decreased [19] [20]. The present study suggests that the decrease in fat accumulation in skeletal muscle in the GR group was affected by the regulation of $\operatorname{C/EBP} \alpha, \operatorname{PPAR} \gamma 2$ and myostatin gene expression. Moreover, moisture content in both muscles of the CT group was significantly lower than that of the GR group (Table 2). These 
results suggest that repartition of nutrient contents may be caused by grazing at the end of fattening.

Table 2 shows the sum of the concentration of fatty acids in the LL and ST muscles of the GR and CT groups. There was no significant difference in saturated fatty acid and monounsaturated fatty acid in either muscle between the two groups. In contrast, polyunsaturated fatty acid (PUFA) in the ST muscle of the GR group was higher than that of the CT group. PUFA in the LL muscle was higher in the GR group than in the CT group, though there was no significant difference between two groups. The PUFA concentration in the muscle of the pastured steers was higher than that of the concentrate-fed steers [8]. Another report shows that a high concentration of PUFA in muscle was detected in the grass-fed cattle compared with cattle fed a combination of grass and concentrate [9]. The high concentration of PUFA in muscle was consistent between the present study and previous studies.

Cooking loss was employed as an index of the water-holding capacity of the meat. The cooking loss in the ST muscle was higher in the GR group compared with the CT group, but there was no significant difference between the groups (Table 2). Several reports describe no difference in cooking loss between concentrate-fed steer and alfalfa silage-fed [21] or grass-fed [14] steers. Our results agreed with these results. However, a previous report observed that cooking loss in muscle is lower in concentrate-fed bulls than in grazed bulls [22]. Cooking loss was not consistent between the different rearing systems from several studies. Further studies are needed to clarify the influence of rearing systems on the cooking loss.

WBSF is used to measure meat tenderness and is the most widely used method to do so. The WBSF in the ST muscle was higher in the GR group than in the CT group, but there was no significant difference between the groups (Table 2). Other studies reported that the shear force of muscle was lower in the concentrate-fed steers compared with the forage-fed [10] and pasture-fed [8] steers. These reports did not correspond with the results obtained in the present study. However, the slight change in the WBSF of the ST muscle between two groups may have been caused by grazing during the short period and/or extractable lipid contents in muscle. Furthermore, Bernard et al. [7] reported that low expression of HSP 40 (DNAJA1) in skeletal muscle of Charolais bull calves is associated with elevated beef tenderness by transcriptomic study. HSP 40 gene expression in the ST muscle was lower in the GR group than in the CT group, but there was no significant difference between two groups (Table 3). Although the present study tended to show a decrease in HSP 40 expression and an increase in the WBSF in ST muscle of the GR group, these results were not strongly supportive of the previous reports [7]. On the other hand, though the WBSF in the LL muscle in the present study was not measured, the results suggested that a decrease in HSP 40 gene expression in the LL muscle of the GR group may affect the beef tenderness (Table 3). Further studies are needed to clarify the correlation between HSP 40 expression and tenderness in skeletal muscle of Japanese Black steers.

Additionally, HSPs have been utilized in several studies as stress markers. Our previous study indicated that an increase in HSP 27 expression in skeletal muscle occurred in a high-density housing stress condition in steers [23]. Moreover, HSP 27 expression in skeletal muscle occurred simultaneously with a decrease in IgG blood levels in the outdoor-grazed steers compared with indoor concentrate-fed steers [23]. Increase in the HSP 27 protein level in skeletal muscle was observed at 1 and 14 days after eccentric exercise stress compared with that before the stress [24]. Transport-stressed pigs show a higher level of HSP 70 in the heart and kidney than do control pigs [25]. In the present study, expression of HSP 27 and HSP 40 genes in the LL muscle of the GR group was significantly lower than that of the CT group (Table 3). These results suggest that grazing of steers may be expected to reduce the influence of stress.

\section{Conclusions}

The present study suggests that an increase in protein content and decrease in fat accumulation in the LL and/or ST muscles of the grazing steers at the end of fattening were affected by the expression of myostatin, MyHC, $\mathrm{PPAR} \gamma 2$, and $\mathrm{C} / \mathrm{EBP} \alpha$ genes. Gene expression of the MyHC isoforms suggest that muscle fiber type conversion to slow-twitch from fast-twitch occurred in grazed steer muscle by grazing and/or exercise stimulus during grazing.

The present study confirmed that gene expression involved in skeletal muscle growth is related to the accumulation of nutrient contents in skeletal muscle between outdoor grazed and indoor concentrate-fed steers. Although the present study measured the expression of only seven genes belonging to three groups, expression analysis of many genes in several groups may be able to obtain a large amount of information about the living 
body. Monitoring gene expression in skeletal muscle can be indicative of biological reactions, such as the protein and fat accumulation in skeletal muscle, during fattening beef cattle, which may be able to provide useful information to alter fattening systems. To alter fattening systems based on gene expression, further studies are needed to elucidate the relationship between gene expression and beef production, including the growth and carcass performance and nutrient contents in skeletal muscle.

\section{Acknowledgements}

The authors appreciate the help of the technical staff at the NARO/WARC. This work was supported in part by a Grant-in-Aid (No. 25450402) for Scientific Research from Ministry of Education, Science, Sports and Culture of Japan.

\section{References}

[1] Shibata, M., Matsumoto, K., Hikino, Y., Oe, M., Ojima, K., Nakajima, I., Muroya, S. and Chikuni, K. (2011) Influence of Different Feeding Systems on the Growth Performance and Muscle Development of Japanese Black Steers. Meat Science, 89, 451-456. http://dx.doi.org/10.1016/j.meatsci.2011.05.006

[2] McPherron, A.C., Lawler, A.M. and Lee, S.J. (1997) Regulation of Skeletal Muscle Mass in Mice by a New TGF- $\beta$ Superfamily Member. Nature, 387, 83-90. http://dx.doi.org/10.1038/387083a0

[3] Lin, F.T. and Lane, M.D. (1992) Antisense CCAAT/Enhancer-Binding Protein RNA Suppresses Coordinate Gene Expression and Triglyceride Accumulation during Differentiation of 3T3-L1 Preadipocytes. Genes and Development, 6, 533-544. http://dx.doi.org/10.1101/gad.6.4.533

[4] Tontonoz, P., Hu, E., Graves, R.A., Budavari, A.I. and Spiegelman, B.M. (1994) mPPAR 2: Tissue-Specific Regulator of an Adipocyte Enhancer. Genes and Development, 8, 1224-1234. http://dx.doi.org/10.1101/gad.8.10.1224

[5] Rosen, E.D. and Spiegelman, B.M. (2000) Molecular Regulation of Adipogenesis. Annual Review of Cell and Developmental Biology, 16, 145-171. http://dx.doi.org/10.1146/annurev.cellbio.16.1.145

[6] Lee, S.J. and McPherron, A.C. (2001) Regulation of Myostatin Activity and Muscle Growth. Proceedings of the National Academy of Sciences of the United States of America, 98, 9306-9311. http://dx.doi.org/10.1073/pnas.151270098

[7] Bernard, C., Cassar-Malek, I., Cunff, M.L., Dubroeucq, H., Renard, G. and Hocquette, J.F. (2007) New Indicators of Beef Sensory Quality Revealed by Expression of Specific Genes. Journal of Agricultural and Food Chemistry, 55, 5229-5237. http://dx.doi.org/10.1021/jf0633721

[8] Muramoto, T., Higashiyama, M. and Kondo, T. (2005) Effect of Pasture Finishing on Beef Quality of Japanese Shorthorn Steers. Asian-Australasian Journal of Animal Science, 18, 42-426.

[9] Srinivasan, S., Xiong, Y.L., Blanchard, S.P. and Moody, W.G. (1998) Proximate, Mineral and Fatty Acid Composition of Semimembranosus and Cardiac Muscles from Grass- and Grain-Fed and Zeranol-Implanted Cattle. Food Chemistry, 63, 543-547. http://dx.doi.org/10.1016/S0308-8146(97)00134-9

[10] Schroeder, J.W., Cramer, D.A., Bowling, R.A. and Cook, C.W. (1980) Palatability, Shelf Life and Chemical Differences between Forage- and Grain-Finished Beef. Journal of Animal Science, 50, 852-859.

[11] Montgomery, J.L., Allen, V.G., Pond, K.R., Miller, M.F., Wester, D.B., Brown, C.P., Evans, R., Bagley, C.P., Ivy, R.L. and Fontenot, J.P. (2001) Tasco-Forage: IV. Influence of a Seaweed Extract Applied to Tall Fescue Pastures on Sensory Characteristics, Shelf-Life, and Vitamin E Status in Feedlot-Finished Steers. Journal of Animal Science, 79, 884894.

[12] AOAC (1990) Official Methods of Analysis. 15th Edition, Association of Official Analytical Chemists, Arlington.

[13] AOCS (2005) Official Methods and Recommended Practices of AOCS. 5th Edition, The American Oil Chemists Society, Urbana.

[14] French, P., O’Riordan, E.G., Monahan, F.J., Caffrey, P.J., Vidal, M., Mooney, M.T., Troy, D.J. and Moloney, A.P. (2000) Meat Quality of Steers Finished on Autumn Grass, Grass Silage or Concentrate-Based Diets. Meat Science, 56, 173-180. http://dx.doi.org/10.1016/S0309-1740(00)00037-1

[15] Shibata, M., Matsumoto, K., Hikino, Y., Oe, M., Ojima, K., Nakajima, I., Muroya, S., Chikuni, K. and Yamamoto, N. (2012) Effect of Grass Hay Feeding on Meat Production, Carcass Characteristics, and Meat Quality in Japanese Black Steers. Bulletin of NARO Western Region Agricultural Research Center, 11, 15-25.

[16] Shibata, M., Matsumoto, K., Oe, M., Kameyama, O.M., Ojima, K., Nakajima, I., Muroya, S. and Chikuni, K. (2009) Differential Expression of the Skeletal Muscle Proteome in Grazed Cattle. Journal of Animal Science, 87, 2700-2708. http://dx.doi.org/10.2527/jas.2008-1486

[17] Demirel, H.A., Powers, S.K., Naito, H., Hughes, M. and Coombes, J.S. (1999) Exercise-Induced Alterations in Skeletal 
Muscle Myosin Heavy Chain Phenotype: Dose-Response Relationship. Journal of Applied Physiology, 86, 1002-1008.

[18] Yamada, T., Kawakami, S.I. and Nakanishi, N. (2007) Effects of Fattening Periods on the Expression of Adipogenic Transcription Factors in Wagyu Beef Cattle. Meat Science, 76, 289-294. http://dx.doi.org/10.1016/j.meatsci.2006.11.010

[19] Lin, J., Arnold, H.B., Della-Fera, M.A., Azain, M.J., Hartzell, D.L. and Baile, C.A. (2002) Myostatin Knockout in Mice Increases Myogenesis and Decreases Adipogenesis. Biochemical and Biophysical Research Communications, 291, 701-706. http://dx.doi.org/10.1006/bbrc.2002.6500

[20] McPherron, A.C. and Lee, S.J. (2002) Suppression of Body Fat Accumulation in Myostatin-Deficient Mice. Journal of Clinical Investigation, 109, 595-601. http://dx.doi.org/10.1172/JCI0213562

[21] Mandell, I.B., Buchanan-Smith, J.G. and Campbell, C.P. (1998) Effects of Forage vs. Grain Feeding on Carcass Characteristics, Fatty Acid Composition, and Beef Quality in Limousin-Cross Steers When Time on Feed Is Controlled. Journal of Animal Science, 76, 2619-2630.

[22] Dufrasne, I., Gielen, M., Limbourg, P., Eenaeme, C. and Istasse, L. (1995) Effects of a Grazing Period on Performance of Finishing Bulls: Comparison with an Indoor Finishing System. Animal Science, 60, 75-80. http://dx.doi.org/10.1017/S1357729800008158

[23] Shibata, M., Hikino, Y., Matsumoto, K. and Yamamoto, N. (2014) Influence of Housing Density and Grazing on Heat Shock Protein 27 Expression in Skeletal Muscle of Beef Cattle. Journal of Fisheries Livestock Production, in Press.

[24] Feasson, L., Stockholm, D., Freyssenet, D., Richard, I., Beckmann, J.S. and Denis, C. (2002) Molecular Adaptations of Neuromuscular Disease-Associated Proteins in Response to Eccentric Exercise in Human Skeletal Muscle. Journal of Physiology, 543, 297-306. http://dx.doi.org/10.1113/jphysiol.2002.018689

[25] Yu, H., Bao, E.D., Zhao, R.Q. and Lv, Q.X. (2007) Effect of Transportation Stress on Heat Shock Protein 70 Concentration and mRNA Expression in Heart and Kidney Tissues and Serum Enzyme Activities and Hormone Concentrations of Pigs. American Journal of Veterinary Research, 68, 1145-1150. http://dx.doi.org/10.2460/ajvr.68.11.1145 
Scientific Research Publishing (SCIRP) is one of the largest Open Access journal publishers. It is currently publishing more than 200 open access, online, peer-reviewed journals covering a wide range of academic disciplines. SCIRP serves the worldwide academic communities and contributes to the progress and application of science with its publication.

Other selected journals from SCIRP are listed as below. Submit your manuscript to us via either submit@scirp.org or Online Submission Portal.
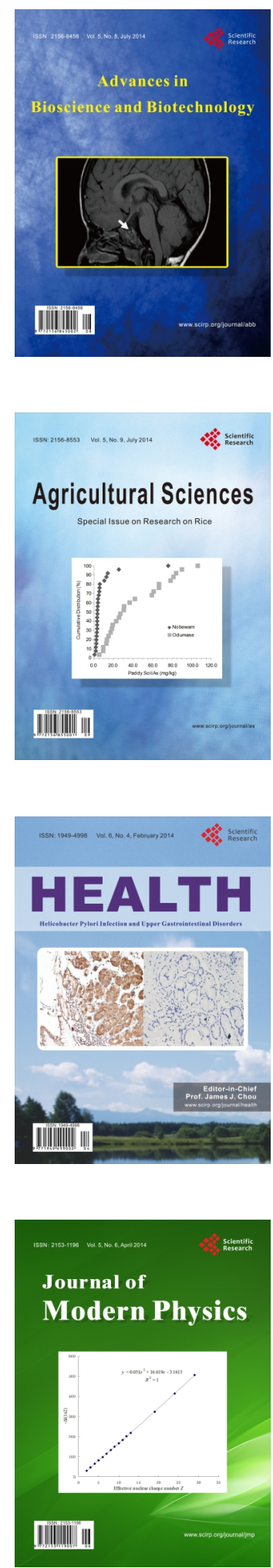
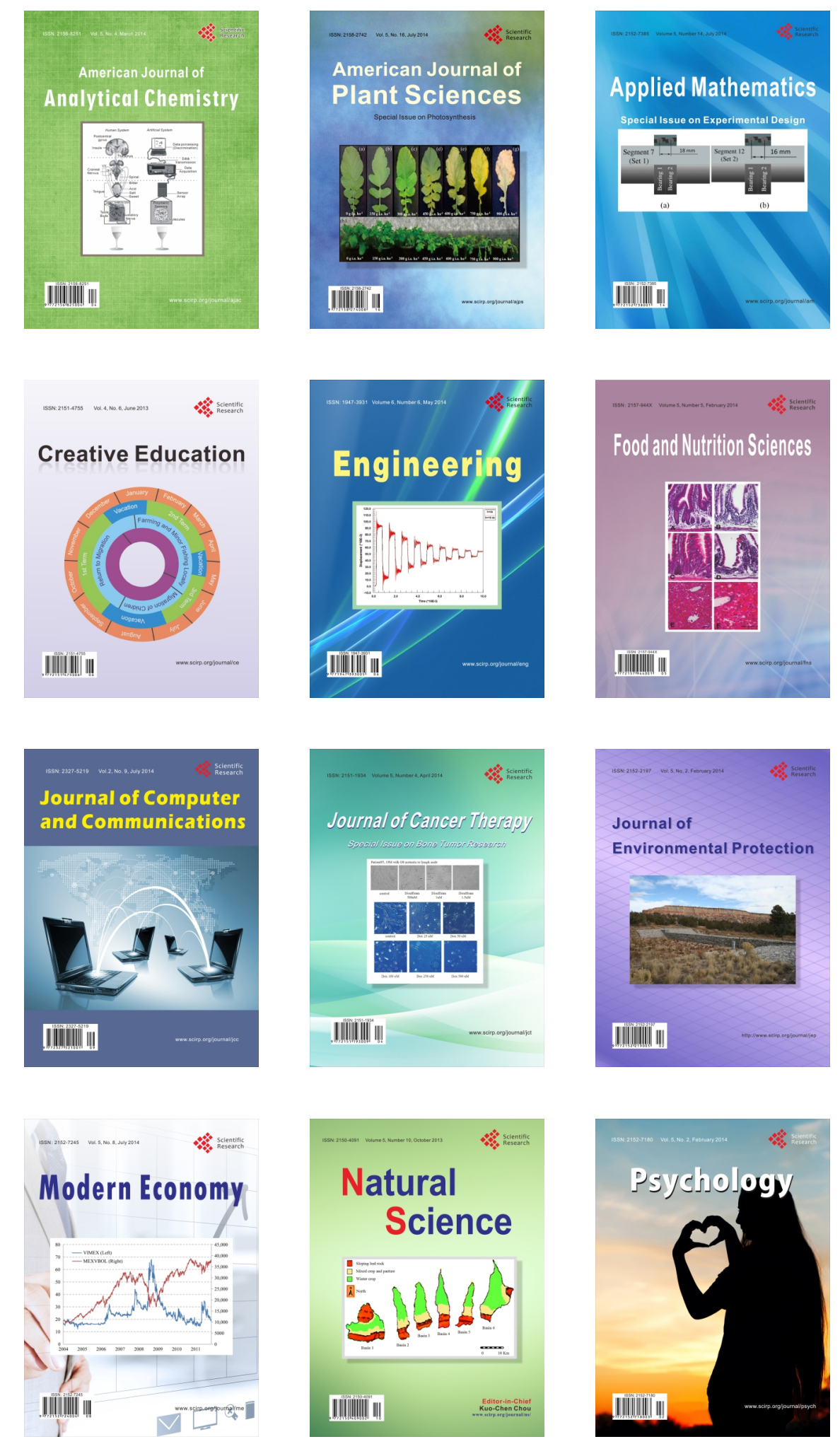